\section{OPEN ACCESS}

Edited by:

Iñigo Muxika,

Technological Center Expert in Marine and Food Innovation (AZTI), Spain

Reviewed by:

Andre Eric Punt,

University of Washington,

United States

Michael Arthur St. John,

Technical University of Denmark,

Denmark

*Correspondence:

Kristen A. Anstead

kanstead@asmfc.org

Specialty section:

This article was submitted to Marine Ecosystem Ecology,

a section of the journal

Frontiers in Marine Science

Received: 17 September 2020

Accepted: 12 April 2021

Published: 07 May 2021

Citation:

Anstead KA, Drew K, Chagaris $D$, Cieri M, Schueller AM, McNamee JE, Buchheister A, Nesslage G, Uphoff

JH Jr, Wilberg MJ, Sharov A,

Dean MJ, Brust J, Celestino M, Madsen S, Murray S, Appelman M,

Ballenger JC, Brito J, Cosby E,

Craig C, Flora $C$, Gottschall $K$,

Latour RJ, Leonard E, Mroch R,

Newhard J, Orner D, Swanson C, Tinsman J, Houde ED, Miller TJ and

Townsend $H$ (2021) The Path to an Ecosystem Approach for Forage Fish

Management: A Case Study of Atlantic Menhaden

Front. Mar. Sci. 8:607657.

doi: 10.3389/fmars.2021.607657

\title{
The Path to an Ecosystem Approach for Forage Fish Management: A Case Study of Atlantic Menhaden
}

\begin{abstract}
Kristen A. Anstead ${ }^{1 *}$, Katie Drew ${ }^{1}$, David Chagaris ${ }^{2}$, Matt Cieri ${ }^{3}$, Amy M. Schueller ${ }^{4}$, Jason E. McNamee ${ }^{5}$, Andre Buchheister 6 , Geneviève Nesslage ${ }^{7}$, Jim H. Uphoff Jr. ${ }^{8}$, Michael J. Wilberg ${ }^{7}$, Alexei Sharov ${ }^{9}$, Micah J. Dean ${ }^{10}$, Jeffrey Brust ${ }^{11}$, Michael Celestino ${ }^{11}$, Shanna Madsen ${ }^{12}$, Sarah Murray ${ }^{1}$, Max Appelman', Joseph C. Ballenger ${ }^{13}$, Joana Brito ${ }^{2,14}$, Ellen Cosby ${ }^{15}$, Caitlin Craig ${ }^{16}$, Corrin Flora ${ }^{17}$, Kurt Gottschall ${ }^{18}$, Robert J. Latour ${ }^{19}$, Eddie Leonard ${ }^{20}$, Ray Mroch ${ }^{4}$, Josh Newhard ${ }^{21}$, Derek Orner ${ }^{22}$, Chris Swanson ${ }^{23}$, Jeff Tinsman ${ }^{24}$, Edward D. Houde ${ }^{7}$, Thomas J. Miller ${ }^{7}$ and Howard Townsend ${ }^{25}$

${ }^{1}$ Atlantic States Marine Fisheries Commission, Arlington, VA, United States, ${ }^{2}$ Nature Coast Biological Station, Institute of Food and Agricultural Sciences, University of Florida, Gainesville, FL, United States, ${ }^{3}$ Maine Department of Natural Resources, Boothbay Harbor, ME, United States, ${ }^{4}$ NOAA Fisheries, Beaufort, NC, United States, ${ }^{5}$ Rhode Island Department of Environmental Management, Providence, RI, United States, ${ }^{6}$ Department of Fisheries Biology, Humboldt State University, Arcata, CA, United States, ${ }^{7}$ Chesapeake Biological Laboratory, University of Maryland Center for Environmental Science, Solomons, MD, United States, ${ }^{8}$ Cooperative Oxford Lab, Maryland Department of Natural Resources, Oxford, MD, United States, ${ }^{9}$ Maryland Department of Natural Resources, Annapolis, MD, United States, ${ }^{10}$ Massachusetts Division of Marine Fisheries, Gloucester, MA, United States, " New Jersey Division of Marine Fisheries, Port Republic, NJ, United States, ${ }^{12}$ Virginia Marine Resources Commission, Hampton, VA, United States, ${ }^{13}$ South Carolina Department of Natural Resources, Charleston, SC, United States, ${ }^{14}$ OKEANOS Research Center, University of the Azores, Horta, Portugal, ${ }^{15}$ Potomac River Fisheries Commission, Colonial Beach, VA, United States, ${ }^{16}$ New York Department of Environmental Conservation, East Setauket, NY, United States, ${ }^{17}$ North Carolina Department of Environmental Quality, Morehead City, NC, United States, ${ }^{18}$ Connecticut Department of Energy and Environmental Protection, Old Lyme, CT, United States, ${ }^{19}$ Virginia Institute of Marine Science, William \& Mary, Gloucester Point, VA, United States, ${ }^{20}$ Georgia Department of Natural Resources, Brunswick, GA, United States, ${ }^{21}$ U.S. Fish and Wildlife Service, Annapolis, MD, United States, ${ }^{22}$ NOAA Fisheries, Silver Spring, MD, United States, ${ }^{23}$ Florida Fish and Wildlife Research Institute, St. Petersburg, FL, United States, ${ }^{24}$ Delaware Division of Fish and Wildlife, Dover, DE, United States, ${ }^{25}$ NOAA Fisheries, Oxford, MD, United States
\end{abstract}

Atlantic menhaden (Brevoortia tyrannus) support the largest fishery by volume on the United States East Coast, while also playing an important role as a forage species. Managers' and stakeholders' increasing concerns about the impact of Atlantic menhaden harvest on ecosystem processes led to an evolution in the assessment and management of this species from a purely single-species approach to an ecosystem approach. The first coastwide stock assessment of Atlantic menhaden for management used a single-species virtual population analysis (VPA). Subsequent assessments used a forward projecting statistical catch-at-age framework that incorporated estimates of predation mortality from a multispecies VPA while analytical efforts continued toward the development of ecosystem models and explicit ecological reference points (ERPs) for Atlantic menhaden. As an interim step while ecosystem models were being developed, a series of ad hoc measures to preserve Atlantic menhaden biomass for predators were used by managers. In August 2020, the Atlantic States Marine Fisheries Commission formally adopted an ecological modeling framework as a tool to set reference points and harvest limits for the Atlantic menhaden that considers their role as a forage fish. This is the first example of a quantitative ecosystem approach to setting reference 
points on the United States Atlantic Coast and it represents a significant advance for forage fish management. This case study reviews the history of Atlantic menhaden stock assessments and management, outlines the progress on the current implementation of ERPs for this species, and highlights future research and management needs to improve and expand ecosystem-based fisheries management.

Keywords: atlantic menhaden, fisheries management, ecosystem based fisheries management, forage fish, ecosystem approaches to fisheries management, ecological reference points, Brevoortia tyrannus

\section{INTRODUCTION}

Over the past several decades, scientists, managers, and stakeholders have expressed increasing interest in ecosystembased fisheries management (EBFM). EBFM is a holistic approach that seeks to manage fisheries for the health and resilience of the ecosystem overall, rather than focusing on maximizing yield or productivity for single species (McLeod and Leslie, 2009; Link, 2010). True EBFM models are designed to provide advice for managing the ecosystem as a whole, which represents a major paradigm shift from the current single-species management framework, to the point that full implementation is often considered prohibitive (Patrick and Link, 2015; Levin et al., 2018). However, ecosystem considerations can be brought into the single-species framework with ecosystem approaches to fisheries management (EAFM). EAFM shares many of the same goals and objectives as EBFM but seeks to develop scientific and policy approaches that build upon existing singlespecies frameworks as opposed to starting with a full ecosystem framework (Link, 2010). Forage fishes have received particular attention in this context because they represent a clear case of competing management objectives that cannot be resolved within purely single-species management; they provide direct socioeconomic benefits to the fisheries that target them, but they also provide direct benefits to the ecosystem as prey and to the fisheries that target their predators (Link, 2010). There is an extensive body of literature on scientific and policy approaches to account for the ecosystem role of forage fishes (e.g., Pikitch et al., 2012), but actual implementation of these approaches has been limited to date (Rice and Duplisea, 2014; Koehn et al., 2020).

Several modeling and management approaches for addressing the role of forage fishes in the ecosystem have been developed including harvest control rules that consider predator needs (e.g., Constable et al., 2000; Pikitch et al., 2012) and the implementation of EBFM (e.g., Fletcher et al., 2010; Fogarty, 2014). Issues for applying EBFM include modeling challenges such as model selection and lack of data (e.g., Link et al., 2012; Rose et al., 2015) and management barriers when authority extends across regulatory bodies and geographic areas (e.g., Fletcher et al., 2010). Various modeling approaches that account for the role of forage fishes in the ecosystem were compared and discussed by Pikitch et al. (2012). The methods used have varied and include biomass thresholds to ensure predators have sufficient food (e.g., krill Euphausia superba in the Antarctic, capelin Mallotus villosus and Atlantic herring Clupea harengus in the Barents Sea, Peruvian anchovy Engraulis ringens) to temperature-dependent quota buffers (e.g., forage fish in California) to spatial or seasonal closures for the fishery (e.g., North Sea sand eels Ammodytes spp., anchovy Engraulis encrasicolus and sardine Sardinops sagax in South Africa; Pikitch et al., 2012).

Atlantic menhaden (Brevoortia tyrannus) are an economically and ecologically important schooling forage fish in the clupeid family that inhabit nearshore Atlantic Ocean waters from Nova Scotia, CAN, to Florida, United States (Figure 1). Atlantic menhaden undergo extensive size- and age-dependent seasonal migrations (Dryfoos et al., 1973; Nicholson, 1978; Liljestrand et al., 2019) and are indeterminate spawners, capable of spawning multiple times in a season in nearshore coastal waters (Ahrenholz, 1991; Southeast Data Assessment and Review [SEDAR], 2020a). Fish may live up to a maximum of 10 years based on scale ages, although individuals aged over six are rarely seen in the fisheries (Southeast Data Assessment and Review [SEDAR], 2015). Juveniles spend most of their first spring and summer in estuaries along the coast and migrate to the nearshore coastal waters and ocean in the late fall. Subadult and adult fish also seasonally inhabit estuarine and coastal habitats. As larvae, Atlantic menhaden feed on zooplankton, but juveniles and adults consume zooplankton and phytoplankton by filtering seawater through specialized gill rakers (June and Carlson, 1971; Friedland, 1985; Lynch et al., 2010). Atlantic menhaden serve as prey for a wide range of species (Nicholson, 1978; Ahrenholz et al., 1987; Munroe and Smith, 2000) that include commerciallyand recreationally-important finfishes such as Atlantic striped bass (Morone saxatilis; Walter et al., 2003), bluefish (Pomatomus saltatrix; Scharf et al., 2004), spiny dogfish (Squalus acanthias; Buckel et al., 1999), and bluefin tuna (Thunnus thynnus; Butler et al., 2010). They are also consumed by birds (e.g., osprey Pandion haliaetus, bald eagle Haliaeetus leucocephalus; Viverette et al., 2007) and marine mammals such as dolphins and humpback whales (Smith et al., 2015). The northwest Atlantic continental shelf (NWACS) ecosystem has a diverse prey base and the prevalence of Atlantic menhaden in the diets of predators varies by season and region, as well as with the age of the predator, the abundance of Atlantic menhaden, and availability of other alternative prey (Chase, 2002; Walter et al., 2003; Butler et al., 2010; Overton et al., 2015).

In addition to their ecological role, Atlantic menhaden have supported the largest commercial fishery by volume, or weight in tonnes, on the Atlantic coast for over a century with landings in 2018 valued at US\$44.5 million (Ahrenholz et al., 1987; National Marine Fisheries Service [NMFS], 2020; Southeast Data Assessment and Review [SEDAR], 2020a). The majority of landings come from the purse seine "reduction" fishery 

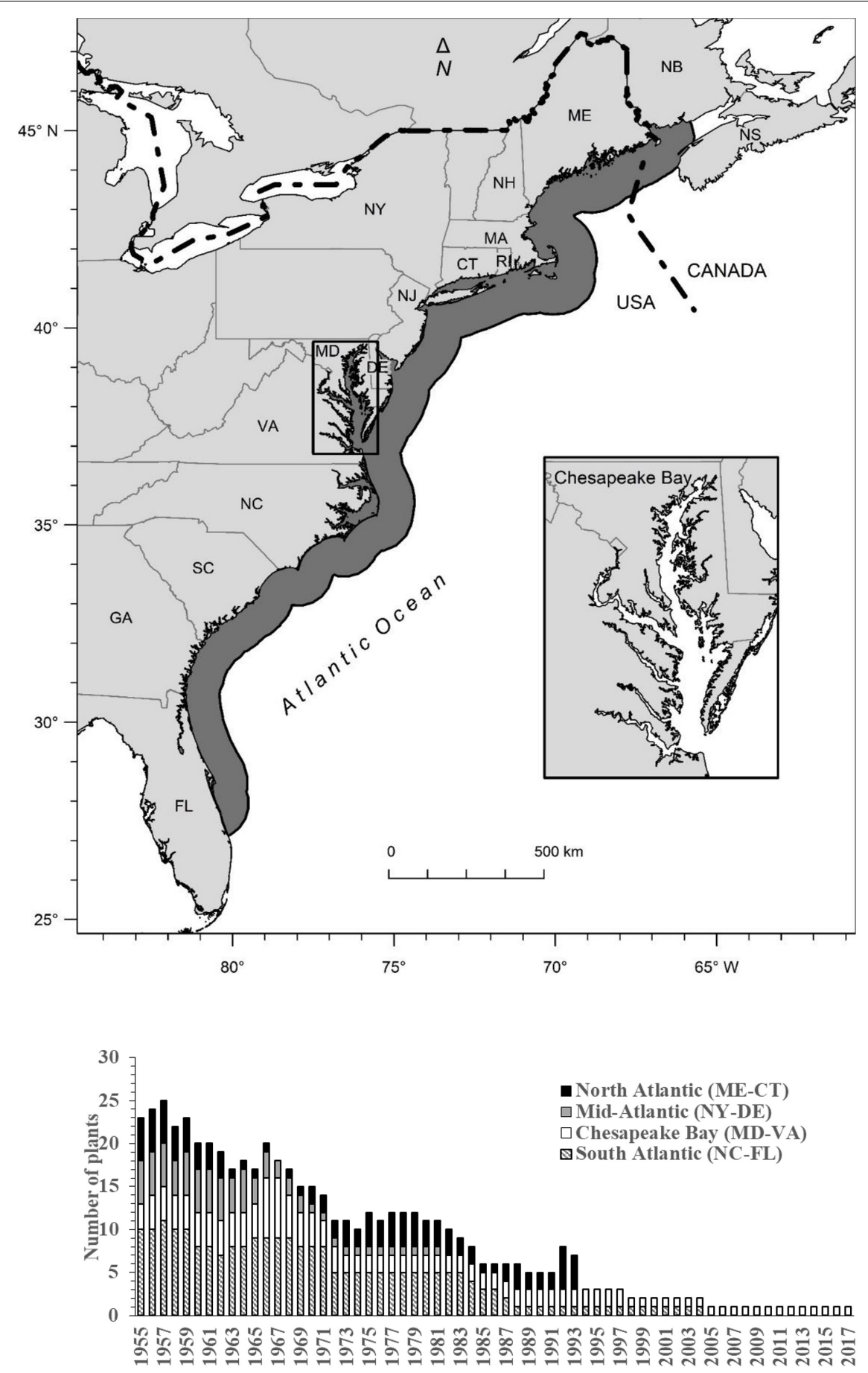

FIGURE 1 | Map of the range of Atlantic menhaden from Nova Scotia, Canada, along the nearshore and coastal waters of the United States Atlantic coast to Florida, top, and the number of reduction plants in operation in the United States by region through time, bottom (Source: NOAA Beaufort).

(Figure 2), which harvest Atlantic menhaden for processing into fish meal and oil. The products are then used in aquaculture feed, poultry and swine feed, fertilizer, pet food, and dietary supplements (Southeast Data Assessment and Review [SEDAR], 2020a). In the 1950s, 25 Atlantic menhaden factories operated in the United States, but today only one reduction plant in
Virginia remains in operation (Figure 1). Atlantic menhaden are also harvested coastwide by mixed gear "bait" fisheries for use in other commercial and recreational fisheries. Bait landings have increased in recent years and currently comprise $25 \%$ of total coastwide landings. This shift is attributed to the shortage of other bait fish, such as Atlantic herring (C. harengus; 


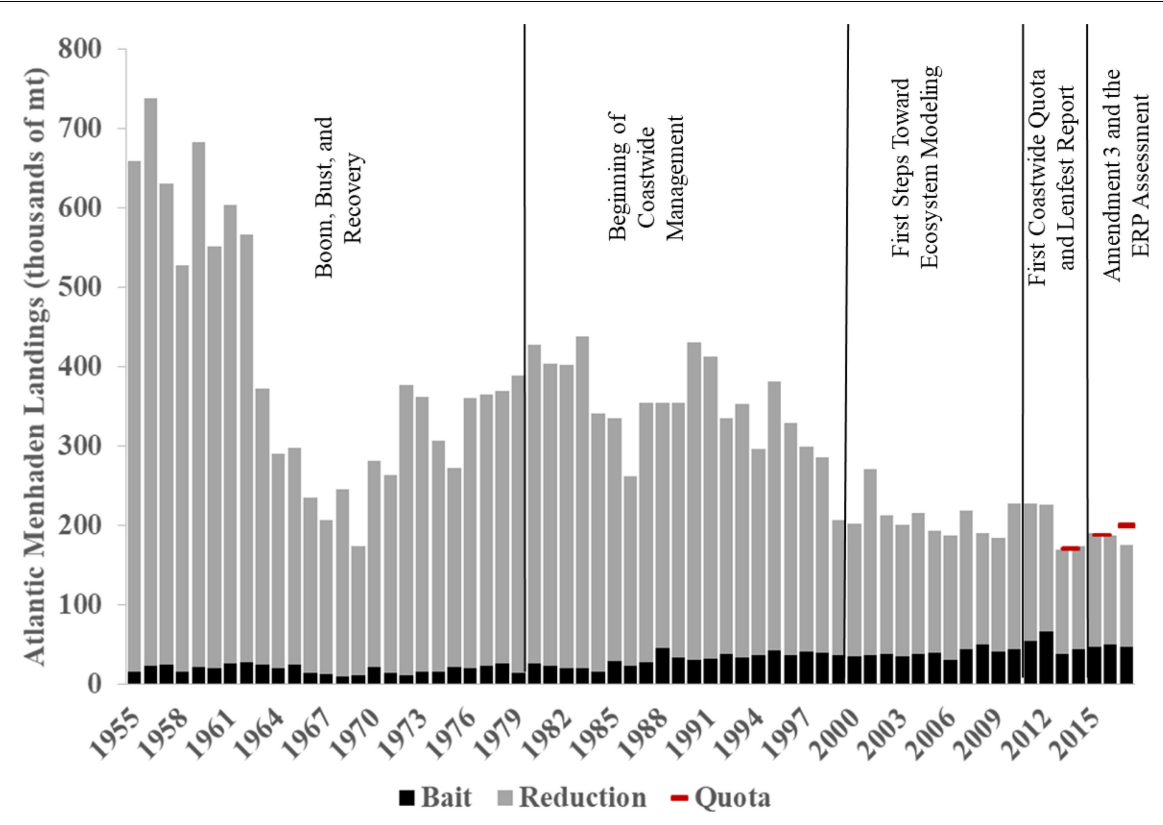

FIGURE 2 | Atlantic menhaden landings from the reduction and bait fisheries during each of the five periods of assessment and management history. Coastwide harvest quotas began in 2013 and are indicated on the graph in red.

Southeast Data Assessment and Review [SEDAR], 2020a). The Atlantic menhaden bait fishery is comprised of small-scale operations that typically also harvest other species as part of their income (Whitehead and Harrison, 2017).

Like many forage species, Atlantic menhaden have undergone large fluctuations in biomass over time (Essington et al., 2016; Southeast Data Assessment and Review [SEDAR], 2020a; Figure 3), as have the predators that rely on them. Recognizing and accounting for the role of Atlantic menhaden in the ecosystem has become a priority for the management of the species (Southeast Data Assessment and Review [SEDAR], 2020a,b). For over two decades, managers, fisheries scientists, and stakeholders have worked together to move the management of Atlantic menhaden beyond a single-species framework and toward an ecosystem approach. The objectives of this case study were to (1) describe the history of Atlantic menhaden management and assessment science to illustrate the development and implementation of an ecosystem approach to forage fish management, (2) highlight the challenges faced and future work needed to advance Atlantic menhaden management, and (3) synthesize the lessons learned from this process that can facilitate advances in the management of other forage fish species.

\section{ASSESSMENT AND MANAGEMENT HISTORY}

Atlantic menhaden are managed by the Atlantic States Marine Fisheries Commission (ASMFC), as the majority of landings historically come from United States state territorial waters (within 3 miles of the coast) rather than United States federal exclusive economic zone waters (3-200 miles from the coast).
ASMFC was established by statute in 1942 to provide a cooperative framework for the management of marine and diadromous stocks that were shared between multiple states on the United States Atlantic Coast. ASMFC currently manages 27 species or groups of species, either solely or jointly with the U.S. Federal Fisheries Management Councils. Individual species Management Boards, made up of representatives from interested states and the federal government, set the broad-scale management regulations for that species' state fisheries. The Atlantic Striped Bass Conservation Act (1984) and Atlantic Coastal Fisheries Cooperative Management Act (1993) gave ASMFC legislative authority for the species it manages. ASMFC is not bound by the Magnuson-Stevens Fishery Conservation and Management Act (1976, subsequent reauthorizations) that governs most United States federalwaters fisheries, and therefore ASMFC can be more flexible when setting management objectives, reference points, and harvest strategies than federally managed species. Species-specific Technical Committees, comprised of state, federal, and academic scientists, conduct stock assessments and provide technical advice to support management for ASMFC-managed species.

\section{0-1980: Boom, Bust, and Recovery}

The industrial-scale purse seine fishery for Atlantic menhaden began in the 1850s in Rhode Island and spread south to the Carolinas by the late 1800s (Southeast Data Assessment and Review [SEDAR], 2020a). The fishery expanded significantly after World War II to become the largest fishery by weight in the United States (Ahrenholz et al., 1987). Annual landings peaked in the late 1950s at approximately 700,000 mt (Figure 2) with over 20 processing plants in operation from Maine through Florida 

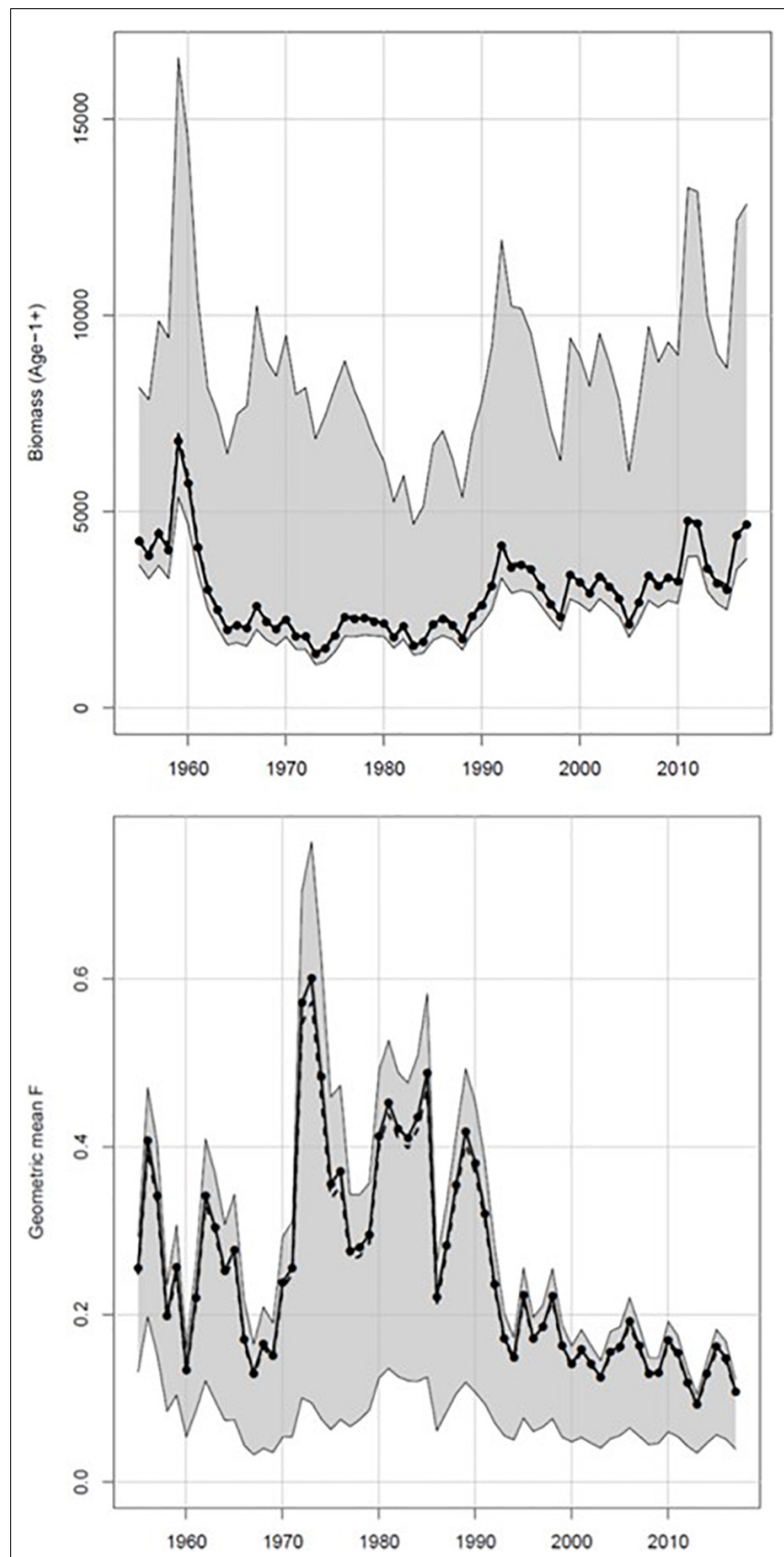

FIGURE 3 | Age 1+ biomass of Atlantic menhaden (in metric tons; top) and geometric mean fishing mortality rate $(F)$ for ages-2 to -4 (bottom) with 95th percentiles from the Monte Carlo Bootstrap method as estimated in the most recent stock assessment (Southeast Data Assessment and Review [SEDAR], 2020a).

(Southeast Data Assessment and Review [SEDAR], 2020a). The population was supported by frequent strong year classes and age-1+ biomass was high (Figure 3). However, in the 1960s, the population declined and the stock contracted geographically. Landings also declined, reaching less than 200,000 $\mathrm{mt}$ in 1969, and processing plants north of Chesapeake Bay began to close. By 1974, only ten processing plants remained active
(Southeast Data Assessment and Review [SEDAR], 2020a). In the 1970s, the stock began to recover as stronger year classes entered the population, and landings increased again, although not to the highs of the 1950s, and a few plants in the Northeast (Maine through Connecticut) reopened.

There was no quota for Atlantic menhaden during this period and states managed the fishery in their waters independently with no consistent coastwide management. Extensive sampling of the reduction fishery catch, including the collection of catchat-age data, began in 1955. This data collection facilitated the development of age-structured models in the 1970s (e.g., Schaaf and Huntsman, 1972; Schaaf, 1975, 1979), although these were not used for coastwide management.

\section{1-1999: Beginning of Coastwide Atlantic Menhaden Management}

Atlantic States Marine Fisheries Commission established the first interstate Fishery Management Plan for Atlantic menhaden in 1981. The plan was revised significantly in 1992 in response to several developments in the 1980s including an improved spawning stock relative to the 1970s, good recruitment, expanded age structure, and the closing of most reduction plants during that decade. These early plans specified management triggers based on the age structure of the catch, spawning stock biomass, spawning potential, and, if necessary, provided options for management action (Atlantic States Marine Fisheries Commission [ASMFC], 1981, 1992). Several states independently introduced season or gear restrictions that curtailed the reduction fishery in their waters. The stock was assessed with a separable Virtual Population Analysis (VPA) during this period (e.g., Vaughan et al., 1986).

Annual landings remained moderately high through the 1980s, averaging around 370,000 $\mathrm{mt}$ (Figure 2). Although all shore-based reduction plants in the Northeast had closed by 1989, mainly because of odor abatement issues with local municipalities, Canadian-based plants and factory ships from the Soviet Union provided alternative markets for landings from that region (Southeast Data Assessment and Review [SEDAR], 2020a). However, landings declined again during the 1990s as adult fish became scarce north of New York and by 1998 only two processing plants remained in operation on the Atlantic coast, one in Virginia and one in North Carolina. Additionally, these two remaining plants reduced their effort, production capacity, and fleet size (Southeast Data Assessment and Review [SEDAR], 2020a).

From the first management plan in 1981, the role of Atlantic menhaden as a forage fish was recognized (Table 1). The early plans highlighted the perceived conflict between the Atlantic menhaden reduction fishery and recreational anglers who targeted the predators of Atlantic menhaden and believed that the Atlantic menhaden fishery was reducing their prey base (Atlantic States Marine Fisheries Commission [ASMFC], 1981). However, recognition of their forage role did not translate into explicit management actions. The VPA used to assess the stock 
TABLE 1 | Key management documents, objectives, reference points, United States coastwide quota levels, and harvest caps on Atlantic menhaden for $1981-2020$.

\begin{tabular}{|c|c|c|c|c|c|}
\hline Year & Management document & Management goals & Reference points & Quota & $\begin{array}{c}\text { Chesapeake bay } \\
\text { cap }\end{array}$ \\
\hline $1981-1991$ & Fishery Management Plan (FMP) & $\begin{array}{l}\text { To maintain harvest at or below MSY, } \\
\text { recognize the role of menhaden in the food } \\
\text { chain, maximize YPR, maintain a stable } \\
\text { business climate }\end{array}$ & $\begin{array}{l}\text { None; Some seasonal } \\
\text { limits and management } \\
\text { triggers }\end{array}$ & & \\
\hline 1992-2000 & FMP Revision & $\begin{array}{l}\text { To manage the Atlantic menhaden fishery } \\
\text { in a manner that is biologically, } \\
\text { economically, and socially sound while } \\
\text { protecting the resource and its users }\end{array}$ & & & \\
\hline 2001 & Amendment 1 & $\begin{array}{l}\text { To manage the Atlantic menhaden fishery } \\
\text { in a manner that is biologically, } \\
\text { economically, socially and ecologically } \\
\text { sound, while protecting the resource and } \\
\text { those who benefit from it }\end{array}$ & $\begin{array}{l}F_{R E P} \text { (threshold) and } \\
F_{M A X} \text { (target), } \\
S S B_{B M S Y p r o x y} \text { (target) and } \\
S S B_{M S S T} \text { (maximum } \\
\text { spawning stock target; } \\
\text { threshold) }\end{array}$ & None & None \\
\hline 2004 & Addendum I & & $\begin{array}{l}F_{\text {REP }} \text { (threshold) and } \\
F_{M A X} \text { (target) and } \\
\text { corresponding FEC } \\
\text { target and threshold }\end{array}$ & & \\
\hline 2005-2009 & Addendum II-IV & & & & $\begin{array}{l}\text { 109,020 mt (for } \\
\text { 2006-2012 fishing } \\
\text { years) }\end{array}$ \\
\hline 2011 & Addendum V & & $\begin{array}{l}F_{15 \% M S P} \text { (threshold) and } \\
F_{30 \% M S P} \text { (target), } \\
S S B_{30 \% M S P} \text { (target) and } \\
S S B_{15 \% M S P} \text { (threshold) }\end{array}$ & & \\
\hline 2012 & Amendment 2 & $\begin{array}{l}\text { Same as Amendment } 1 \text { and to minimize } \\
\text { the chance of a population decline due to } \\
\text { overfishing, reduce the risk of recruitment } \\
\text { failure, reduce impacts to species which } \\
\text { are ecologically dependent on Atlantic } \\
\text { menhaden, and minimize adverse effects } \\
\text { on participants in the fishery }\end{array}$ & & $\begin{array}{c}170,800 \mathrm{mt} \text { (for } \\
\text { 2013-2014 fishing } \\
\text { years) }\end{array}$ & $\begin{array}{c}87,216 \mathrm{mt} \text { (beginning } \\
\text { in the } 2013 \text { fishing } \\
\text { year) }\end{array}$ \\
\hline 2015-2016 & & & $\begin{array}{l}F_{21 \% M S P} \text { (threshold) and } \\
F_{36 \% M S P} \text { (target), } \\
F E C_{21 \% M S P} \text { (threshold) } \\
\text { and } F E C_{36 \% M S P} \text { (target) }\end{array}$ & $187,880 \mathrm{mt}$ & \\
\hline 2017 & Amendment 3 & $\begin{array}{l}\text { To manage the fishery in a manner which } \\
\text { equitably allocates the resource's } \\
\text { ecological and economic benefits between } \\
\text { all user groups-those who fish menhaden } \\
\text { and the predators that rely on menhaden, } \\
\text { and those whose livelihood depends on } \\
\text { the health of the marine ecosystem }\end{array}$ & & $200,000 \mathrm{mt}$ & \\
\hline 2018-2020 & & & & $216,000 \mathrm{mt}$ & $51,000 \mathrm{mt}$ \\
\hline 2020 & & & $\begin{array}{l}\text { ERP } F \text { threshold and } \\
\text { target and corresponding } \\
\text { FEC threshold and target }\end{array}$ & $\begin{array}{l}194,400 \mathrm{mt} \text { (for the } \\
2021-2022 \text { fishing } \\
\text { years) }\end{array}$ & \\
\hline
\end{tabular}

See text for a description of each reference point.

at this time incorporated an age- and time-constant estimate of natural mortality ( $M$, or the loss in the population due to causes other than fishing, such as disease or predation) based on tagging data, but the 1999 peer review of the assessment recommended a multispecies approach to capture the impact of changes in predator populations on Atlantic menhaden mortality rates (Atlantic States Marine Fisheries Commission [ASMFC], 1999).

\section{0-2010: First Steps Toward Atlantic Menhaden Ecosystem Modeling and Management}

In 2001, Amendment 1 to the Atlantic menhaden management plan specifically added ecological objectives, including maintaining the important ecological role menhaden play along the coast (Atlantic States Marine Fisheries Commission [ASMFC], 2001). At this time, ASMFC also began funding the development of a multispecies model for Atlantic menhaden to account for their role in the ecosystem. The resulting Expanded Multispecies VPA model (MSVPA-X model) was a set of singlespecies VPA models that were linked by a predator consumption model, which allowed for the calculation of predation mortality on Atlantic menhaden (Northeast Fisheries Science Center [NEFSC], 2006; Garrison et al., 2010). The MSVPA-X explicitly modeled Atlantic menhaden, striped bass, bluefish, and weakfish (Cynoscion regalis), all of which are managed solely or jointly by ASMFC. These species were also chosen because diet data indicated Atlantic menhaden were an important component and all three predator species had seen an increase in their 
population sizes since the early 1990s, raising concerns that predation mortality may increase on Atlantic menhaden and predator biomass and growth may be limited. This model was intended to better quantify predator and prey interactions and account for these effects on Atlantic menhaden, specifically through the development of time- and age-varying $M$ estimates. The MSVPA-X was not developed enough to replace the singlespecies assessments, set reference points, or set harvest limits for the modeled species, but was still able to inform the $M$ values used in the single-species stock assessment for Atlantic menhaden by providing estimates of time-varying $M$-at-age.

In 2004, the single-species Atlantic menhaden assessment switched from a VPA to a forward-projecting statistical catchat-age model, known as the Beaufort Assessment Model or BAM (Williams and Shertzer, 2015). This model allowed the separation of bait and reduction fleets, as well as the incorporation of fishery-independent indices of abundance (Atlantic States Marine Fisheries Commission [ASMFC], 2004). The MSVPA-X was used to develop age-specific estimates of $M$ for input into the 2004 assessment, and time- and age-varying estimates of $M$ for the 2010 assessment, both using BAM. The BAM has remained the preferred single-species assessment model to this day.

Atlantic States Marine Fisheries Commission uses reference points to establish the status of a stock (whether the stock is overfished or experiencing overfishing) as well as to set quotas and harvest strategies to control fishing mortality. The 2004 assessment found that the stock was not overfished and overfishing was not occurring relative to the reference points at that time (Table 1 ), the fishing mortality rate ( $F$, or the loss in the population due to fishing) corresponding to the median observed spawning biomass to recruitment ratio (also called $F_{R E P}$, or $F_{R E P L A C E M E N T}$; Sissenwine and Shepherd, 1987). However, managers and stakeholders expressed concerns about the potential for localized depletion of Atlantic menhaden within the Chesapeake Bay. The Chesapeake Bay is the largest estuary in the United States, located in the center of the range of Atlantic menhaden (Figure 1), and is an important nursery ground for many species on the Atlantic Coast, including Atlantic menhaden and several commercially and recreationally valuable predator species. Atlantic menhaden's landings along the coast and within the Chesapeake Bay had declined over the past decade, but with the closures of more northern reduction plants, the proportion of landings from the Chesapeake Bay had increased compared to historical levels (Atlantic States Marine Fisheries Commission [ASMFC], 2005). In 2005, the reduction plant in North Carolina closed, leaving only one plant in Virginia still in operation.

Juvenile Atlantic menhaden abundance indices in the Chesapeake Bay had declined to low levels in the 1990s and early 2000s (Atlantic States Marine Fisheries Commission [ASMFC], 2004), and observations of striped bass in poor condition increased in the Chesapeake Bay along with an outbreak of lesions and an epizootic of mycobacteriosis (Uphoff, 2003; Walter et al., 2003). This caused increased concern from recreational and environmental stakeholders and organizations about the effect of Atlantic menhaden abundance on striped bass health (Vogelbein et al., 1999; Uphoff, 2003; Atlantic States Marine Fisheries Commission [ASMFC], 2004). As a result, managers and stakeholders worried that Atlantic menhaden abundance in the Chesapeake Bay could be reduced below the level that would be sufficient to maintain their basic ecological functions (e.g., forage base, important link with primary productivity). In response to these concerns, ASMFC implemented an ad hoc harvest cap on the reduction fishery in the Chesapeake Bay starting in 2006 (Table 1). The cap limited the removals of Atlantic menhaden from the Chesapeake Bay for reduction purposes to $109,020 \mathrm{mt}$, the average of the 2001-2005 reduction landings from the Bay. Total coastwide landings of Atlantic menhaden averaged approximately $217,000 \mathrm{mt}$ per year for the same period but there was no coastwide quota for Atlantic menhaden at that time. The Chesapeake Bay harvest cap was intended as a precautionary measure to prevent the expansion of the reduction fishery in an ecologically important region, representing the first management measure that was explicitly intended to consider Atlantic menhaden's role as a forage fish.

During this time, work continued on complementary ecosystem modeling efforts relevant to Atlantic menhaden. The National Oceanic and Atmospheric Administration's (NOAA) Chesapeake Bay Office developed the Fisheries Ecosystem Planning for the Chesapeake Bay report (National Oceanic and Atmospheric Administration Chesapeake Bay Fisheries Ecosystem Advisory Panel [NOAA CBFEAP], 2006), the first ecosystem plan for United States fisheries, which described the Bay's ecosystem, species interactions, habitats, and ecosystembased approaches for management. NOAA's Chesapeake Bay Office also organized a peer review of existing research programs on Atlantic menhaden and ecosystem dynamics within the Chesapeake Bay in an attempt to answer the question of whether localized depletion was occurring. The result was inconclusive: without an operational definition of depletion, it could not be determined whether localized depletion was occurring or how well the ongoing research could address that question (Maguire, 2009). Additionally, Christensen et al. (2009) developed an Ecopath with Ecosim (EwE) model for the Chesapeake Bay that included Atlantic menhaden. EwE is a dynamic food web model that simulates changes in biomass across whole ecosystems (Christensen and Walters, 2004). Christensen et al. (2009) only intended to provide ecosystem advice for the Chesapeake Bay, so while the EwE modeled more species and provided more information about Atlantic menhaden's role in the ecosystem than the MSVPA-X, it missed important dynamics between Atlantic menhaden and their predators during their migrations outside of the Chesapeake Bay.

\section{1-2014: First Coastwide Quota and Lenfest Report}

The 2010 stock assessment indicated the stock was experiencing overfishing, although it was not overfished relative to the singlespecies reference points at that time (Atlantic States Marine Fisheries Commission [ASMFC], 2011; Table 1). The peer review of the 2010 assessment recommended considering alternative reference points to $F_{R E P}$ since the stock had been at low levels of population fecundity for several years and the current reference points were not protecting the spawning stock relative to the unfished level. Following the assessment, the Atlantic Menhaden Technical Committee was tasked with developing 
options for alternative reference points that accounted for predation. Acknowledging that development of these reference points would require expertise beyond the Technical Committee, the Ecological Reference Point Work Group (ERP WG) was appointed in 2012 and was comprised of members of relevant single-species committees and groups that had worked on previous menhaden multispecies efforts.

In response to the recommendations from the peer review, reference points were developed based on percent of maximum spawning potential (MSP). The 2010 assessment used a timeand age-varying $M$ based on output from the MSVPA-X, so predation in recent years was incorporated into those reference points, but this approach did not fully satisfy managers in terms of accounting for Atlantic menhaden's role as a forage fish. In 2012, ASMFC implemented Amendment 2 to the management plan to adopt single-species reference points based on percent MSP, with the $F$ threshold set at $F_{15 \% M S P}$ and the $F$ target set at $F_{30 \% M S P}$ (Table 1). Amendment 2 specified that singlespecies reference points would be applied until scientists could develop ERPs, defined in that document as reference points that account for the broader ecological roles and services that Atlantic menhaden provide (Atlantic States Marine Fisheries Commission [ASMFC], 2012). Overfishing was still occurring relative to those new single-species reference points. To reduce $F$, Amendment 2 also implemented the first coastwide quota for Atlantic menhaden. Other measures to allocate catch across states and improve catch reporting and biosampling in the bait fishery were also implemented (Atlantic States Marine Fisheries Commission [ASMFC], 2012). The annual quota was set at $170,800 \mathrm{mt}$ and represented a 20\% reduction from 2009 to 2011 average landings. The cap on annual reduction fishery removals from the Chesapeake Bay was also reduced by $20 \%$, to $87,216 \mathrm{mt}$. Some small-scale operations (0-2 employees) were not affected by the decreased quota but larger-scale operations faced reductions in landings, income, and workforce (Whitehead and Harrison, 2017). Also in response to the quota, the one remaining reduction factory in Virginia decreased the size of its fleet.

At approximately the same time, the Lenfest Forage Fish Task Force released a report (Pikitch et al., 2012) that provided recommendations for managing forage fish in an ecosystem context based on extensive meta-analyses of existing ecosystem models and literature from several regions around the world, including the Chesapeake Bay EwE model developed by Christensen et al. (2009). Pikitch et al. (2012) recommended a precautionary approach for forage fish management to ensure sustainability of both predator and prey species. Recommendations included fishing at 50-75\% of $F_{M S Y}$ and adopting a biomass threshold of 30-40\% of unexploited biomass, depending on the amount and quality of data available for a given system and fishery. These findings were in line with other concurrent research on forage fish management (e.g., Walters et al., 2005; Smith et al., 2011). The Pikitch et al. (2012) report received attention outside of scientific circles and increased awareness of and interest in ecosystem approaches to fishery management among stakeholders.

Other research on Atlantic menhaden-specific ecosystem analyses occurred independently of the ERP WG. Buchheister et al. (2017a,b) developed an EwE model that covered the NWACS ecosystem with data from 1982 to 2013, extending the Chesapeake Bay modeling by Link et al. (2008) and Christensen et al. (2009). The NWACS EwE model included 61 trophic groups, from plankton to finfish, birds and marine mammals, and eight fishing fleets. The model estimated the impacts of different levels of Atlantic menhaden harvest on the biomass and yield of other species (Buchheister et al., 2017a,b).

\section{5-2020: Amendment 3 and the ERP Assessment}

Atlantic menhaden were assessed again in 2015 and the singlespecies reference points were redefined. Instead of using $F_{15 \% M S P}$ as the threshold and $F_{30 \% M S P}$ as the target, the stock assessment recommended setting the $F$ reference points based on a period when the stock was considered to be experiencing sustainable fishing mortality and the $F$ threshold and target were defined as the maximum and median geometric mean fishing mortality rate for ages 2-4 during 1960-2012 (Southeast Data Assessment and Review [SEDAR], 2015). The new threshold and target resulted in a higher percent maximum spawning percentage than the previous reference points, equivalent to an $F_{21 \% M S P}$ and $F_{36 \% M S P}$, respectively (Table 1), and were more conservative than the previous reference points. This stock assessment found that Atlantic menhaden were not overfished and not experiencing overfishing relative to their single-species reference points, but improvements to model structure and data resulted in a revision to historical stock status, indicating $F$ had been below both the target and the threshold since 2000, even under the new, more conservative reference points (Southeast Data Assessment and Review [SEDAR], 2015).

In response to these findings, ASMFC initiated the development of Amendment 3, which focused on the reallocation of the commercial quota between the states and the path toward adoption of ERPs (Atlantic States Marine Fisheries Commission [ASMFC], 2017). However, the ERPs were not ready for use in management at the time. As a result, public comment was sought on several options: (1) ending the ERP WG's work and using only the single-species reference points going forward; (2) using interim generalized forage fish reference points based on literature (e.g., Pikitch et al., 2012 or Smith et al., 2011) until Atlantic menhaden-specific ERPs were available; and (3) using single-species reference points until Atlantic menhaden-specific ERPs were available.

Atlantic States Marine Fisheries Commission received over 157,000 comments from the public in favor of some form of ERPs compared to seven comments in favor of only using singlespecies reference points going forward, illustrating the public interest and awareness of the issue and the desire to move to an ecosystem management regime. The Atlantic Menhaden Management Board voted to continue to use the single-species reference points until the ERP WG's work was completed and peer-reviewed. To provide interim protection for ecosystem services, the Board used an ad hoc approach to set the coastwide quota at 187,880 $\mathrm{mt}$ for 2015-2016 and 216,000 $\mathrm{mt}$ for 20172018, an increase from the 2012 to 2014 quota, but $31 \%$ less 
than the quota recommended if the stock were fished at the single-species target $F$ rate $(314,500 \mathrm{mt}$ in 2018). The Board also reduced the Chesapeake Bay reduction harvest cap from 87,216 to $51,000 \mathrm{mt}$, approximately equal to the average reduction landings from the Bay over the previous 5-year period and a $41 \%$ decrease from the previous cap. An economic impact analysis was conducted to evaluate different quota levels and the associated changes to jobs and revenue (Whitehead and Harrison, 2017).

As part of the 2015 assessment, the ERP WG presented a suite of preliminary ERP models and ecosystem monitoring approaches for consideration (Southeast Data Assessment and Review [SEDAR], 2015). Problems arose with the MSVPA-X during the assessment, particularly with the MSVPA-X being unable to capture the same population trends as the more complex BAM single-species assessments and with the laborintensive nature of the modeling process (Southeast Data Assessment and Review [SEDAR], 2015). As a result, the development of the MSVPA-X was shelved in favor of the other approaches.

To continue the work, the ERP WG needed concrete guidance from the Atlantic Menhaden Management Board about their specific ecosystem and fisheries goals and objectives for the management of Atlantic menhaden. While there is longstanding precedent for what constitutes single-species fishery management objectives, there are no standardized objectives for multispecies management as the objectives depend on the specific context of the fisheries and ecosystem involved. This difference created some confusion, as the managers wanted technical expertise on the ERPs first, but the ERP WG required managers' input on objectives to proceed with development. To address this, ASMFC convened a workshop in 2015. Participants included ASMFC managers, fishery and ecosystem stakeholders, and scientists. At the workshop, fundamental ecosystem management objectives, as well as their associated performance measures, were identified through a structured decision-making process (Peterman and Anderson, 1999; Irwin et al., 2011; Table 2). These objectives included ensuring sustainability of Atlantic menhaden to provide for directed Atlantic menhaden fisheries, ensuring sustainability of Atlantic menhaden to provide for predators and the fisheries they support, providing stability for Atlantic menhaden and predator fisheries, and minimizing risk due to a changing environment (Atlantic States Marine Fisheries Commission [ASMFC], 2015). The objectives were not prioritized or ranked, and the competing nature of some of these objectives indicated that the models used to develop ERPs for Atlantic menhaden must evaluate the trade-offs between Atlantic menhaden harvest and predator harvest or biomass to provide managers with the information most relevant to their needs.

In 2017, the development of both single-species and ERP stock assessments began on parallel tracks with significant overlap in committee membership to provide consistency and facilitate information sharing. The single-species assessment updated the BAM model and developed single-species reference points for Atlantic menhaden. The ERP WG explored a suite of five models, most of which had been introduced in Southeast Data Assessment and Review [SEDAR] (2015), to develop ERPs. These approaches ranged in complexity, from minimally complex with few data requirements and assumptions, to very complex, with extensive data needs and detailed assumptions. The least complex models were a surplus production model with a timevarying intrinsic growth rate (Nesslage and Wilberg, 2019) and a two-species Steele-Henderson surplus production model with predation (Uphoff and Sharov, 2018). The models of intermediate complexity focused on a small set of key predator and prey species. The first model of intermediate complexity was a multispecies statistical catch-at-age model, which linked traditional statistical-catch-at-age models for the focal species through trophic interaction equations (McNamee, 2018). The second was the NWACS Model of Intermediate Complexity for Ecosystem assessment (NWACS-MICE), a simplified version of the NWACS EwE model that focused on a smaller set of predator and prey species (Chagaris et al., 2020; Southeast Data Assessment and Review [SEDAR], 2020b). The most complex model was an updated version of full ecosystem model, the NWACS EwE model (Buchheister et al., 2017a,b). These models were described fully, along with the species included in each model, how the parameters were estimated, the outputs, and a comparison of the results in Chagaris et al. (2020) and Drew et al. (2021) but are summarized here in Table 3. The suite of models was chosen to evaluate the trade-offs between complexity, realism, and data requirements, as well as to explore the impacts of model structure and assumptions on population trends and reference points.

Five key predator and prey species (termed "focal species") were identified based on their importance as a predator of Atlantic menhaden or as an alternative prey for Atlantic menhaden predators and the quality of the available data for each species (Southeast Data Assessment and Review [SEDAR], 2020b). Striped bass, bluefish, spiny dogfish, and weakfish were key predatory species of Atlantic menhaden. Weakfish were included as both an Atlantic menhaden predator and a prey item for the other predators. Atlantic herring was included as a key alternative prey to Atlantic menhaden for the predators identified. All five focal species are managed either solely or jointly by ASMFC. Not all models included all species, and some models included more species; for example, the NWACS-MICE model also included anchovies (Anchoa spp.) as an alternative prey, and the full NWACS EwE model included many additional predators, such as finfishes, sharks, birds, and marine mammals. However, the focal species approach ensured a minimum set of predators with consistent input data was used in the intermediate complexity models.

The ERP models were developed using datasets for Atlantic menhaden and the focal species that were as consistent as possible across models. Life history information, landings, and abundance indices from the single-species stock assessment were used for Atlantic menhaden, as well as estimates of fishing mortality and biomass from BAM. All focal species had recently undergone single-species stock assessments, which provided life history, landings, and index data through 2017, as well as estimates of fishing mortality and population size. Newer data were not available for all of the groups included in the full NWACS EwE model; as a result, inputs for those groups were extrapolated from the terminal year of 2013 . 
TABLE 2 | Fundamental objectives for ecosystem management of Atlantic menhaden and their associated performance metrics, as identified by Atlantic States Marine Fisheries Commission [ASMFC], 2015.

\section{Fundamental Objectives}

Achieve broad public support for management

Sustain menhaden to provide for fisheries

Sustain menhaden to provide for predators

Sustain menhaden to provide for historical and cultural values

Sustain menhaden to provide for ecosystem services

Minimize risk to sustainability due to changing environment

Provide stability for all types of fisheries

Sustain ecosystem resiliency or stability

\section{Performance measures}

Unanimous vote of the Atlantic Menhaden Management Board

Positive press releases from all stakeholders

"Informed consent" or acknowledgment that the decisions made were "fair and reasonable" Participation in the fishery benefits

Absence of legal action

Strong compliance with management measures

Meeting or exceeding (positively) reference points

Non-truncated age distribution

Historical distribution maintained

Avoid unintended economic consequences of management

Employment in fishery

Achieving yield objectives for all fisheries

Achieving abundances that exceed "depleted" status

Reduce regulatory discards

Same as for fishery, assuming reference points are ecological reference points

Predators in a healthy nutritional state

Distribution of menhaden related to predator requirements (prey availability)

Maintaining "historical" (meaning existing and recent past infrastructure rather than distant past) patterns of employment (spatial, demographic, gear use, etc.)

Same as above; represented in the other menhaden "services"

Analysis would explicitly consider uncertainty about future environmental conditions

Variability for employment and yield

Frequency of substantive management action

Covered by metrics above; if successful in providing for a viable fishery and other food web components that are related to menhaden

TABLE 3 | Summary of models explored in the development of ecological reference points for Atlantic menhaden.

\begin{tabular}{|c|c|c|c|c|c|c|}
\hline Attributes & $\begin{array}{l}\text { Single-species } \\
\text { statistical } \\
\text { catch-at-age }\end{array}$ & $\begin{array}{l}\text { Surplus } \\
\text { production model } \\
\text { w/time-varying } r\end{array}$ & $\begin{array}{c}\text { Surplus } \\
\text { production model } \\
\text { Steele- } \\
\text { Henderson }\end{array}$ & $\begin{array}{l}\text { Multi-species } \\
\text { statistical } \\
\text { catch-at-age }\end{array}$ & $\begin{array}{l}\text { Intermediate } \\
\text { complexity Ecopath } \\
\text { with Ecosim } \\
\text { (NWACS-MICE) }\end{array}$ & $\begin{array}{c}\text { Full Ecopath with } \\
\text { Ecosim (NWACS } \\
\text { EwE) }\end{array}$ \\
\hline Model structure & Age-structured & Pooled biomass & Pooled biomass & Age-structured & $\begin{array}{c}\text { Pooled biomass with } \\
\text { age stanzas }\end{array}$ & $\begin{array}{l}\text { Pooled biomass } \\
\text { with age stanzas }\end{array}$ \\
\hline Start year & 1955 & 1957 & 1957 & 1985 & 1985 & 1982 \\
\hline End year & 2017 & 2017 & 2017 & 2017 & 2017 & 2017 \\
\hline Trophic interactions & None & None & Top down & Top down & Top down, bottom up & $\begin{array}{c}\text { Top down, bottom } \\
\text { up }\end{array}$ \\
\hline $\begin{array}{l}\text { Number of species or } \\
\text { functional groups } \\
\text { included }\end{array}$ & 1 & 1 & 2 & 6 & 11 & 48 \\
\hline $\begin{array}{l}\text { Provides information on } \\
\text { menhaden biomass } \\
\text { and yield }\end{array}$ & $\checkmark$ & $\checkmark$ & $\checkmark$ & $\checkmark$ & $\checkmark$ & $\checkmark$ \\
\hline $\begin{array}{l}\text { Provides information on } \\
\text { predator biomass and } \\
\text { yield }\end{array}$ & & & & $\checkmark$ & $\checkmark$ & $\checkmark$ \\
\hline $\begin{array}{l}\text { Total time-series used } \\
\text { for fitting }\end{array}$ & 15 & 4 & 5 & 84 & 28 & 68 \\
\hline $\begin{array}{l}\text { Overfishing Threshold } \\
\text { Reference Point } \\
\text { Definition }\end{array}$ & $\begin{array}{c}\text { Maximum } \\
\text { geometric mean } F \\
\text { on ages } 2-4 \text { from } \\
1960 \text { to } 2012\end{array}$ & $75 \% U_{M S Y}-2017$ & $F_{M U P-2017}$ & $F_{40 \%-2017}$ & $\begin{array}{c}F_{M S Y} \text { for age- } 1+ \\
\text { Atlantic menhaden }\end{array}$ & $\begin{array}{l}F_{M S Y} \text { for age } 1-2 \\
\text { and age-3+ } \\
\text { Atlantic menhaden }\end{array}$ \\
\hline Overfishing Status & Not overfishing & Not overfishing & Not overfishing & Not overfishing & Not overfishing & Not overfishing \\
\hline
\end{tabular}

Adapted from Drew et al. (2021). 
The ERP WG evaluated the five ERP models based on their performance (i.e., residuals, sensitivities, and other diagnostics), their strengths and weaknesses, and their ability to inform the fundamental ecosystem management objectives (Buchheister et al., 2017a,b; McNamee, 2018; Uphoff and Sharov, 2018; Nesslage and Wilberg, 2019; Chagaris et al., 2020). The ERP WG ultimately recommended using the NWACS-MICE model rather than the other four for two reasons. First, the EwE framework used by the NWACS-MICE model was the only approach that could address both the top-down effects of predation on Atlantic menhaden and the bottom-up effects of Atlantic menhaden on predator populations, which were required to evaluate the key tradeoffs between Atlantic menhaden harvest and predator needs that were central to the identified ecosystem objectives. Second, the NWACS-MICE implementation was less data-intensive than the full NWACS model, which reduced some of the uncertainty associated with modeling the data-poor predators and prey in the full model. This meant the NWACS-MICE model could be updated more quickly and efficiently, on a timeframe that met manager's needs. Comparisons of the full and MICE versions of the NWACS model indicated that the NWACS-MICE model included the fish predators most sensitive to the menhaden population. Striped bass was the most sensitive fish predator to Atlantic menhaden harvest in both models. In the full NWACS model, nearshore piscivorous birds were also sensitive to Atlantic menhaden $F$, but their response was similar to striped bass over the range of scenarios explored by the full model (Southeast Data Assessment and Review [SEDAR], 2020b). This choice was consistent with a growing body of literature that has recommended models of intermediate complexity (i.e., MICE) for ecosystems as representing a compromise between complexity/realism and uncertainty for use in management (Plagányi et al., 2014; Collie et al., 2016; Punt et al., 2016). Specifically, the ERP WG recommended using the NWACSMICE in conjunction with the single-species assessment model, BAM; the NWACS-MICE model would provide strategic advice about the trade-offs between Atlantic menhaden fishing mortality and predator biomass to set reference points, while the singlespecies model would be used to provide short-term tactical advice about harvest strategies to achieve the ERP F target (Chagaris et al., 2020; Southeast Data Assessment and Review [SEDAR], $2020 b)$. The ERP report was peer-reviewed with the singlespecies assessment in 2019, and the ERP WG's recommended tool was deemed acceptable for management use by a panel of independent experts (Southeast Data Assessment and Review [SEDAR], 2020b). The peer-review panel also recommended the continued development of the alternative models going forward.

\section{CURRENT MANAGEMENT}

The development and implementation of ERPs for Atlantic menhaden was a lengthy process (Figure 4 and Table 1), but in August 2020, ASMFC adopted the approach from the ERP WG for management use. The ERP target was defined as the maximum $F$ on Atlantic menhaden that would sustain striped bass at their biomass target when striped bass were fished at their
$F$ target. The ERP threshold was defined as the maximum $F$ on Atlantic menhaden that would keep striped bass at its biomass threshold when striped bass was fished at its $F$ target. For both reference points, all other species in the model were fished at their status quo (i.e., 2017) F rates. Striped bass was the focal predator species for this analysis because it was the most sensitive to Atlantic menhaden $F$ in both the NWACS-MICE and the full NWACS models. Thus, levels of Atlantic menhaden $F$ that sustain striped bass should also sustain piscivorous birds and less sensitive predators, in the absence of significant disruptions to the ecosystem (Southeast Data Assessment and Review [SEDAR], 2020b). With these ERP targets and thresholds, the Atlantic Menhaden Management Board reviewed projections from the single-species model, BAM, and set a quota for 2021 and 2022 of 194,400 mt, a 10\% decrease in the quota from 2020.

The ERP WG explored a range of scenarios for the other focal species (i.e., not Atlantic menhaden or striped bass) and found that the NWACS-MICE model was sensitive to the population level of Atlantic herring, resulting in higher $F$ reference points for Atlantic menhaden when Atlantic herring was at its biomass target and lower $F$ reference points when Atlantic herring was below its biomass threshold as compared to the status quo scenario. Atlantic herring are an important prey item for striped bass in some seasons and regions. However, this sensitivity is likely due to the lack of seasonal and spatial dynamics in the NWACS-MICE model rather than reflecting true ecosystem dynamics. When a seasonal forcing function was added to the striped bass-Atlantic herring relationship, the sensitivity of the model was significantly reduced and the $F$ target values were similar across multiple scenarios. The status quo 2017 scenario most closely approximated short-term conditions for the ecosystem; this assumption can be revisited after additional analysis to incorporate seasonal dynamics into the NWACSMICE model as part of the next stock assessment, which is scheduled for 2025 .

The ERP target and threshold $F$ were lower than the singlespecies target and threshold $F$. The $F$ value from the NWACSMICE model was on a different scale than the $F$ values from the single-species model due to differences in model structure. The single-species model is a statistical catch-at-age model that estimates an annual full $F$, the instantaneous fishing mortality rate that the fully selected age class experiences, while the NWACSMICE model is an EwE model that uses an exploitation rate to drive the population based on the proportion of age-1+ biomass removed by the fishery each year. As a result, although both models report an $F$, estimates of $F$ reference points from the NWACS-MICE model are not directly comparable to estimates of annual $F$ from the single-species model. Therefore, the NWACSMICE model $F$ values were scaled to the single-species values for use in management. The NWACS-MICE model produced a tradeoff curve relating menhaden $F$ to striped bass biomass, in an equilibrium context. From this relationship, Atlantic menhaden $F$ multipliers were identified that would maintain striped bass at their biomass target or threshold, when striped bass were fished at their $F$ target. The $F$ multipliers that produced these conditions were then applied to the single-species model estimate of full $F$ in the terminal year to produce the ERP target and threshold 


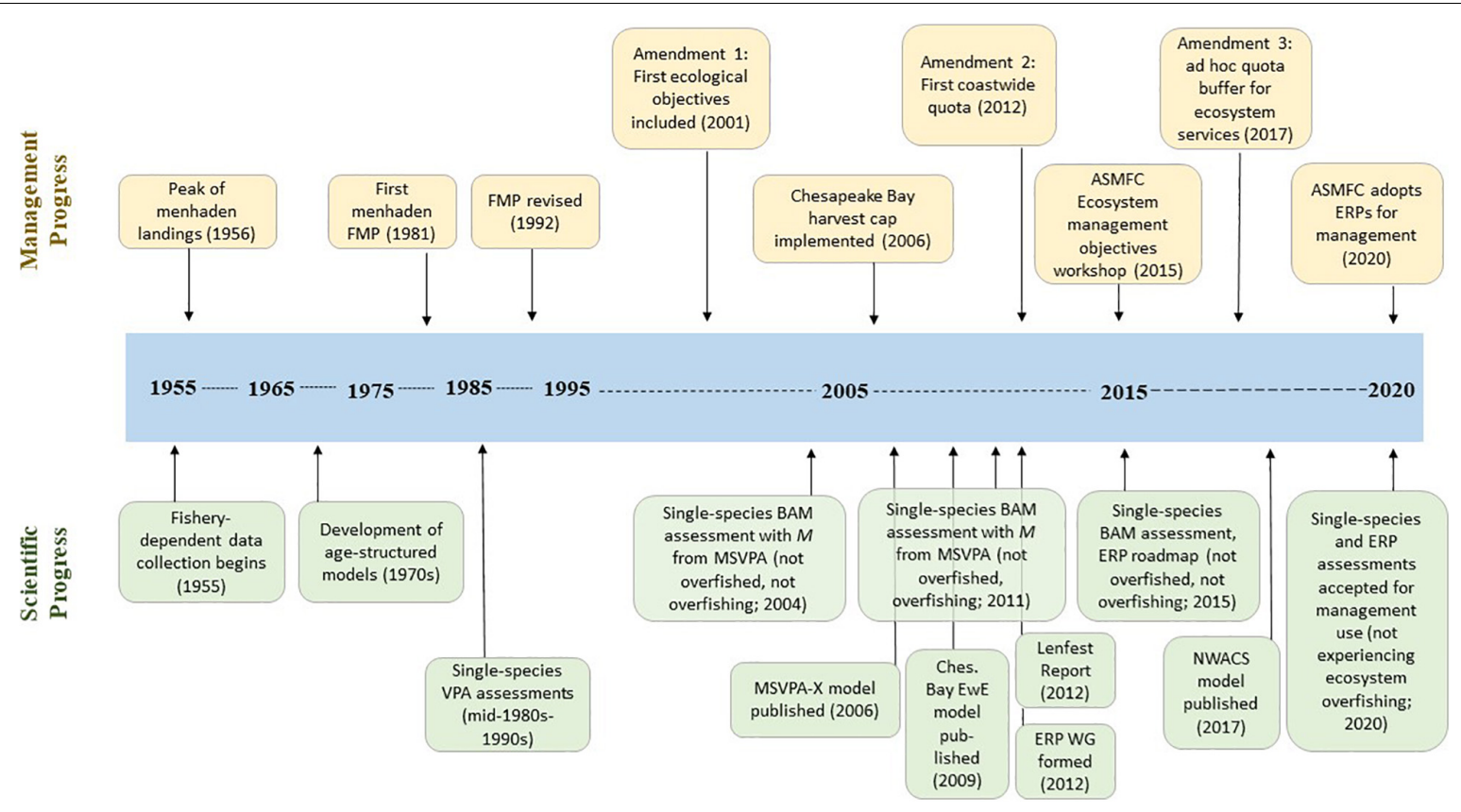

FIGURE 4 | Timeline of significant steps in management and science for Atlantic menhaden and the development of ecological reference points (ERPs).

on the same scale as the single-species model. The ERP target was estimated at a full $F$ (i.e., maximum $F$-at-age) of 0.19 on the single-species model scale, compared to a target $F$ of 0.31 for the single-species model. The ERP threshold was estimated at a full $F$ of 0.57 on the single-species model scale, compared to a threshold $F$ of 0.86 from the single-species model. The 2017 estimate of full $F$ from the single-species model was 0.16 , below both the ERP target and threshold, indicating that Atlantic menhaden were not experiencing ecosystem overfishing in 2017.

\section{CHALLENGES AND FUTURE WORK}

Atlantic States Marine Fisheries Commissions adoption of ERPs for Atlantic menhaden is the first application of quantitative ecological models in management on the United States East Coast and represents a significant step forward for forage fish management in the United States and beyond. However, there is still much work to be done on both the science and the policy side to fully and successfully implement ecosystem-based fishery management for this region. There were modeling, data, and management challenges identified through this process and there is work to be done in the future to address these challenges as the fishery progresses toward EBFM.

\section{Data Requirements}

The models are only as good as the data and more data is needed. The ERP assessment sourced data on diet, abundance, and life history for the focal species from peer reviewed and unpublished literature as well as from long-term state and federal monitoring programs. The collection of diet data along the Atlantic coast needs to be expanded to provide seasonally and regionally stratified annual, year-round monitoring of key predator diets to provide information on prey abundance and predator consumption at a finer scale. This could be done through existing data collection programs with an increase in funding and effort. In addition, a long-term research need is improved monitoring of population trends and diet data in non-finfish predators such as birds and marine mammals and prey species such as bay anchovy, sand lances (Ammodytes spp.), and benthic invertebrates to better characterize the full ecosystem dynamics.

\section{Modeling}

With the exception of the surplus production models, the ERP models were developed with age- or size-structure for Atlantic menhaden and the focal species to address different selectivities on the size of fish captured depending on the fishery and gear used. Improving the impacts of selectivities on model results is an important goal, including the exploration of time-varying selectivities. The current NWACS-MICE model did not fully capture the variability of Atlantic menhaden recruitment. Some of this uncertainty was mitigated by the use of the single-species model, which did capture that observed variability, to provide short-term tactical advice informed by recent recruitment. More work is needed to incorporate realistic levels of recruitment variability into the NWACS framework. A key ecosystem management objective is to reduce risk for Atlantic menhaden and their predators due to a changing environment. Consequently, more research is required to understand the relationship between specific environmental drivers and recruitment and mortality for Atlantic menhaden and the focal species. Finally, the ERP models developed for 
this assessment lacked seasonal and spatial dynamics, which are important to more fully understand the interaction between Atlantic menhaden and their predators (Buchheister et al., 2016). These species undergo extensive, overlapping migrations, and preliminary runs of the NWACS-MICE model indicated that assumptions about the seasonal availability of prey can impact model results.

\section{Management}

Another challenge faced was understanding and quantifying uncertainty in this process given the data needs and modeling assumptions. The multi-model approach and accompanying sensitivity analyses used for the ERP assessment helped characterize uncertainty from model structure and assumptions, but more work needs to be done to quantify the uncertainty in the NWACS-MICE output and the uncertainty introduced by translating between models. A management strategy evaluation (MSE) could be part of this process, to help translate uncertainty in to risk for management consideration. An MSE for Atlantic menhaden could provide a framework to define management goals with various stakeholders, including those from multiple species, and assess the tradeoffs between management objectives in an ERP context. Additionally, it could be valuable for incorporating socioeconomic data, evaluating the robustness to uncertainty of reference points and control rules, and possibly provide an opportunity to evaluate the benefits of improved data collection (Southeast Data Assessment and Review [SEDAR], 2020a). While the data and models that provide scientific ecosystem management advice can and should be improved further, changes to the management structure and process will be necessary to move full EBFM forward. The NWACS-MICE tool can explore a wide range of ecosystem scenarios for the key ERP species in terms of long-term biomass levels or $F$ rates to set reference points and evaluate tradeoffs between Atlantic menhaden and their predator species. However, managers are limited in the scenarios they can explore because the targets and thresholds for the other key ERP species are set by singlespecies management plans and separate Management Boards within ASMFC, and, in some cases, in collaboration with the federal Fisheries Management Councils. Management objectives for these species, including $F$ and biomass targets for each species, are currently set independently of each other.

The ERPs developed here represent an ecosystem approach to fisheries management; they account for ecosystem considerations in the management of a single species (Link, 2010). True EBFM abandons the single-species framework in favor of a full ecosystem framework. The path to true EBFM will require the discussion of trade-offs between Atlantic menhaden and their predators occurring across Boards and agencies to develop consistent management objectives for individual species and the ecosystem. Expanding from the key ERP species identified here to management of the full ecosystem will require integrating state, federal, and ASMFC management bodies to bring managers and stakeholders of all ecosystem species together to evaluate tradeoffs and set management objectives. This is a significant shift in how fisheries management in the United States operates and will not be a quick or easy change. But incremental progress toward fuller ecosystem-based management is still possible.

In addition to ASMFC's efforts, the New England Fishery Management Council has also made progress toward ecosystem management with the development of Amendment 8 to the Atlantic herring fishery management plan. This amendment proposed a harvest control rule that would explicitly account for Atlantic herring's role as forage by limiting $F$ to $80 \%$ of $F_{M S Y}$ when biomass is high and setting it at zero when biomass is low. Although this is a different approach from ASMFC's ERPs, it is attempting to meet the same objective of incorporating ecosystem considerations into management, representing the potential for parallel instead of fully integrated ecosystem approaches in the near term. An ecosystem indicator approach was recently developed for the San Francisco Bay Pacific herring (Clupea pallasii) fishery (Thayer et al., 2020) that differs from the Atlantic menhaden approach but also provides a path for assessing and managing forage fishes. Additionally, Howell et al. (2021) contrast the ecosystem based approach the United States took as described here with that of the Irish Sea. The full implementation of ecosystem-based fishery management on the United States East Coast may not be realized for many years, but there are achievable intermediate steps along this path, starting with Atlantic menhaden ERPs, that have significant value for managers, stakeholders, and the ecosystem.

\section{LESSONS LEARNED}

Many aspects of the Atlantic menhaden fishery make its management unique compared to other forage fishes. For example, the largest sector, the reduction fishery, is no longer a multi-state operation. Therefore, the majority of socioeconomic impacts of adopting ERPs for the Atlantic menhaden fishery will affect one large operator rather than numerous smaller operators as is the case for many other forage species. Other aspects of the fishery also likely aided adoption of ERPs, such as its relationship with striped bass and their shared management agency. The role of high-profile or charismatic predators is not unique to Atlantic menhaden; for example, a network of marine protected areas were established in South Africa to prohibit sardine fishing around African penguin (Spheniscus demersus) colonies (e.g., Pichegru et al., 2010) and areas were closed to fishing in Alaska to protect forage for Steller sea lions (Eumetopias jubatus; National Marine Fisheries Service [NMFS], 2003). However, ASMFC also manages striped bass in addition to Atlantic menhaden, a circumstance which likely made the development and progression to EAFM easier than had they been managed by different agencies. Despite some aspects of the Atlantic menhaden fishery that make it unique, this case study could be a formula for implementing ERPs for other species complexes. All forage fish management bodies and science groups could benefit from clearly defined objectives, the identification of key predator species of interest, the exploration of multiple models, and the recognition of trade-offs made for management. There were several important and broadly applicable lessons learned from this experience that could help 
others along the path to implementing EAFM and hopefully, 1 day, EBFM (Table 4).

\section{Data Requirements}

\section{Align Stock Assessment Schedules of Key Species}

All of the focal species had single-species stock assessments with a terminal year of 2017. This meant that all input data for these species - total removals, indices of abundance, life history data, and stock assessment outputs - were collected and vetted by the appropriate technical committees and available for the ERP WG to incorporate into ecosystem models. Purposefully aligning the key single-species assessments in the future will benefit future assessment updates and benchmark assessments.

\section{Modeling}

\section{Consider a Multi-Model Approach}

The multi-model approach, rather than selecting a single model from the outset, allowed trade-offs between model complexity and data requirements to be evaluated. Also, it allowed the uncertainty due to model structure and assumptions to be better understood by comparing similarities and differences across model predictions and outputs (Drew et al., 2021). This approach led to the development of a tool that combined the strengths of two different models, using the ecosystem dynamics captured by the NWACS-MICE model to provide long-term strategic advice, while the more detailed population dynamics of the singlespecies model provided short-term tactical advice. The model development process focused on consistent data inputs across models wherever possible and identifying consistent outputs and metrics to make comparisons across models as informative and useful as possible.

\section{Form a Dedicated Workgroup}

Having a dedicated ERP WG, which included not just expertise in ecosystem modeling but also expert knowledge of the population and fisheries dynamics of Atlantic menhaden and other key ERP species, allowed for the preservation of institutional knowledge and maintained consistency through the long development process. Additionally, a standing workgroup showed commitment from the ASMFC and state and federal agencies to pursuing EAFM for Atlantic menhaden.

\section{Management Define Both Biological and Socioeconomic Objectives Through Early Engagement of Managers and Stakeholders}

Incorporating ecosystem considerations into management can be achieved through a wide range of scientific and management approaches. The appropriate approach will depend on the specific context of the fishery and ecosystem, as well as manager preferences on the tradeoffs amongst competing ecosystem and socioeconomic objectives. The 2015 workshop brought together managers, scientists, and stakeholders to develop concrete objectives for the ecological management of Atlantic menhaden. The participants also developed performance metrics that could be used to determine whether those objectives were being met. This framework was essential to the ERP WG's process, allowing the group to evaluate candidate models based on whether or not they provided necessary information to managers, and having this information sooner would have made the process more efficient. Establishing clear goals and objectives at the beginning of the process is crucial. In addition, continued stakeholder pressure kept the process of developing and adopting ERPs a high priority for ASMFC and shaped the final implementation.

\section{Engage a Diversity of Collaborators and Funding Sources}

Close collaboration among managers, stock assessment scientists, and academia introduced a range of expertise and models into the development of ERPs. Additionally, a significant amount of funding external to the ASMC was critical to the completion of the models included in the assessment, including from NOAA, Lenfest Ocean Program, The Nature Conservancy, and United States state agencies. Sustained financial investment

TABLE 4 | Key lessons learned from the ASMFC ERP assessment.

Challenges faced

Lack of clear and explicit ecosystem objectives to guide the technical development of ERPs

Gathering and vetting data streams to support data intensive models

Understanding and quantifying uncertainty

Ecosystem models require significant levels of expertise, funding, and time

Full EBFM requires a huge paradigm shift in assessment and management structures
Lessons learned

Early engagement with managers and stakeholders to obtain clear objectives will improve the utility and increase buy-in to the final tool

Mediated workshops with multiple stakeholders was needed to formalize ecosystem objectives

Aligning stock assessment schedules of key species provided the best available data MICE models reduce some of this burden

Using a multi-model approach produced a stronger result in terms of understanding structural uncertainty and leveraging model strengths to reduce uncertainty Sensitivity analyses and MSE can help quantify uncertainty

Collaboration with state, federal, and academic partners brought in a wide range of expertise External funding was critical for the suite of models developed and greatly expanded the scope of what ASMFC could have accomplished alone

Stakeholder engagement with managers kept ERP development a priority despite the amount of time and resources required

Embrace incremental progress

Intermediate steps like ERPs are possible and valuable, and lay the groundwork for further changes in management and science 
is needed to develop the modeling tools to support Atlantic menhaden EAFM and EBFM, although the amount of investment is expected to decrease with fully developed tools.

\section{Embrace Incremental Progress}

Atlantic States Marine Fisheries Commissions ERP assessment represents over two decades of work by Commission, state, federal, and academic scientists to bring ecosystem management from a purely theoretical concept into practical application. Full EBFM represents a huge paradigm shift in the assessment and management structures from the states up through the federal and international levels. Intermediate steps and approaches can be achieved for both the science and the policy components. These can then set the stage for more advanced models and a more comprehensive EBFM in the future. The implementation of ERPs for Atlantic menhaden that are embedded within the existing single-species management framework represents an important intermediate step, allowing ecosystem considerations

\section{REFERENCES}

Ahrenholz, D. W. (1991). Population biology and life history of the North American menhadens. Brevoortia spp. Mar. Fish. Rev. 53, 3-19.

Ahrenholz, D. W., Nelson, W. R., and Epperly, S. P. (1987). Population and fishery characteristics of Atlantic menhaden. Brevoortia tyrannus. Fish. Bull. 85, 569-600.

Atlantic States Marine Fisheries Commission [ASMFC] (1981). Fishery Management Plan for Atlantic Menhaden. Arlington, VA: Atlantic States Marine Fisheries Commission, 146.

Atlantic States Marine Fisheries Commission [ASMFC] (1992). Fishery Management Plan for Atlantic Menhaden: 1992 Revision. Atlantic States Marine Fisheries Commission, Fishery Management Report No. 22. Arlington, VA: Atlantic States Marine Fisheries Commission, 159.

Atlantic States Marine Fisheries Commission [ASMFC] (1999). Atlantic Menhaden Stock Assessment Report for Peer Review. Atlantic States Marine Fisheries Commission, Stock Assessment Report No. 00-01 (Supplement). Arlington, VA: Atlantic States Marine Fisheries Commission, 166.

Atlantic States Marine Fisheries Commission [ASMFC] (2001). Amendment 1 to the Interstate Fishery Management Plan for Atlantic Menhaden. Atlantic States Marine Fisheries Commission, Fishery Management Report No. 37. Arlington, VA: Atlantic States Marine Fisheries Commission, 127.

Atlantic States Marine Fisheries Commission [ASMFC] (2004). Atlantic menhaden stock assessment report for peer review. Atlantic States Marine Fisheries Commission, Stock Assessment Report No. 04-01 (Supplement). Arlington, VA: Atlantic States Marine Fisheries Commission, 145.

Atlantic States Marine Fisheries Commission [ASMFC] (2005). Addendum II to Amendment 1 to the Interstate Fishery Management Plan for Atlantic Menhaden. Arlington, VA: Atlantic States Marine Fisheries Commission.

Atlantic States Marine Fisheries Commission [ASMFC] (2011). Stock Assessment Report No. 10-02 of the Atlantic States Marine Fisheries Commission Atlantic Menhaden Stock Assessment and Review Panel Reports. Arlington, VA: Atlantic States Marine Fisheries Commission, 326.

Atlantic States Marine Fisheries Commission [ASMFC] (2012). Amendment 2 to the Interstate Fishery Management Plan for Atlantic menhaden. Arlington, VA: Atlantic States Marine Fisheries Commission, 114.

Atlantic States Marine Fisheries Commission [ASMFC] (2015). Ecosystem Management Objectives Workshop Report. 10 p. Available online at: http: //www.asmfc.org/files/Meetings/2015AnnualMeeting/AtlMenhadenBoard.pdf (accessed July 26, 2019).

Atlantic States Marine Fisheries Commission [ASMFC] (2017). Amendment 3 to the Interstate Fishery Management Plan for Atlantic Menhaden. Arlington, VA: Atlantic States Marine Fisheries Commission, 111. to be brought into Atlantic menhaden management while work continues on improving modeling and data collection and restructuring the management framework.

\section{AUTHOR CONTRIBUTIONS}

All authors listed have made a substantial, direct, and intellectual contribution to the work and approved it for publication.

\section{FUNDING}

Development of the surplus production model with time-varying intrinsic growth was supported by Maryland Sea Grant Award under award No. NA4OAR4170090 from the National Oceanic and Atmospheric Administration. Development of the EwE-Full and EwE-MICE models were supported by two Lenfest Ocean Program Grant nos. 00025536 and 00032187.

Buchheister, A., Miller, T. J., and Houde, E. D. (2017a). Evaluating ecosystembased reference points for Atlantic menhaden. Mar. Coast. Fish. 9, 457-478. doi: 10.1080/19425120.2017.1360420

Buchheister, A., Miller, T. J., Houde, E. D., and Loewensteiner, D. A. (2017b). Technical Documentation of the Northwest Atlantic Continental Shelf (NWACS) Ecosystem Model. Report to the Lenfest Ocean Program, Washington, D.C. University of Maryland Center for Environmental Sciences Report TS-694-17. Available online at: http://hjort.cbl.umces.edu/NWACS/TS_694_17_NWACS_ Model_Documentation.pdf (accessed May 26, 2018).

Buchheister, A., Miller, T. J., Houde, E. D., Secor, D. H., and Latour, R. J. (2016). Spatial and temporal dynamics of Atlantic Menhaden (Brevoortia tyrannus) recruitment in the Northwest Atlantic Ocean. ICES J. Mar. Sci. 73, 1147-1159. doi: 10.1093/icesjms/fsv260

Buckel, J. A., Fogarty, M. J., and Conover, D. O. (1999). Mutual prey of fish and humans: a comparison of biomass consumed by bluefish, Pomatomus saltatrix, with that harvested by fisheries. Fish. Bull. 97, 776-785.

Butler, C. M., Rudershausen, P. J., and Buckel, J. A. (2010). Feeding ecology of Atlantic bluefin tuna (Thunnus thynnus) in North Carolina: diet, daily ration, and consumption of Atlantic menhaden (Brevoortia tyrannus). Fish. Bull. 108, 56-69.

Chagaris, D., Drew, K., Schueller, A., Cieri, M., Brito, J., and Buchheister, A. (2020). Ecological reference points for atlantic menhaden established using an ecosystem model of intermediate complexity. Front. Mar. Sci. 7:1043. doi: $10.3389 /$ fmars.2020.606417

Chase, B. C. (2002). Differences in diet of Atlantic bluefin tuna (Thunnus thynnus) at five seasonal feeding grounds on the New England continental shelf. Fish. Bull. 100, 168-180.

Christensen, V., Beattie, A., Buchanan, C., Ma, H., Martell, S. J. D., Latour, R. J., et al. (2009). Fisheries Ecosystem Model of the Chesapeake Bay: Methodology, Parameterization, and Model Explanation. U.S. Dep. Commerce, NOAA Tech. Memo. NMFS-F/SPO-106. Annapolis, MD: National Oceanic and Atmospheric Administration. 146.

Christensen, V., and Walters, C. (2004). Ecopath with ecosim: methods, capabilities, and limitations. Ecol. Model. 172, 109-139. doi: 10.1016/j. ecolmodel.2003.09.003

Collie, J. S., Botsford, L. W., Hastings, A., Kaplan, I. C., Largier, J. L., Livingston, P. A., et al. (2016). Ecosystem models for fisheries management: finding the sweet spot. Fish Fisheries 17, 101-125. doi: 10.1111/faf.12093

Constable, A. J., de la Mare, W. K., Agnew, D. J., Everson, I., and Miller, D. (2000). Managing fisheries to conserve the Antarctic marine ecosystem: practical implementation of the Convention on the Conservation of Antarctic Marine Living Resources (CCAMLR). ICES J. Mar. Sci. 57, 778-791. doi: 10.1006/jmsc. 2000.0725 
Drew, K., Cieri, M., Schueller, A. M., Buchheister, A., Chagaris, D., Nesslage, G., et al. (2021). Balancing model complexity, data requirements, and management objectives in developing ecological reference points for Atlantic Menhaden. Front. Mar. Sci. 8:608059. doi: 10.3389/fmars.2021.608059

Dryfoos, R. L., Cheek, R. P., and Kroger, R. L. (1973). Preliminary analyses of Atlantic menhaden, Brevoortia tyrannus, migrations, population structure, survival and exploitation rates, and availability as indicated from tag returns. Fish. Bull. 71, 719-734.

Essington, T. E., Levin, P. S., Marshall, K. N., Koehn, L., Anderson, L. G., Bundy, A., et al. (2016). Building Effective Fishery Ecosystem Plans: A Report From the Lenfest Fishery Ecosystem Task Force. Washington, DC: Lenfest Ocean Program.

Fletcher, W. J., Shaw, J., Metcalf, S. J., and Gaughan, D. J. (2010). An ecosystem based fisheries management framework: the efficient, regional-level planning tool for management agencies. Mar. Policy 34, 1226-1238. doi: 10.1016/j. marpol.2010.04.007

Fogarty, M. (2014). The art of ecosystem-based fishery management. Can. J. Fish. Aquat. 71, 479-490. doi: 10.1139/cjfas-2013-0203

Friedland, K. D. (1985). Functional morphology of the branchial basket structures associated with feeding in the atlantic menhaden, Brevoortia tyrannus (Pisces: clupeidae). Copeia 1985, 1018-1027. doi: 10.2307/1445257

Garrison, L. P., Link, J. S., Kilduff, D. P., Cieri, M. D., Muffley, B., Vaughan, et al. (2010). An expansion of the MSVPA approach for quantifying predatorprey interactions in exploited fish communities. ICES J. Mar. Sci. 67, 856-870. doi: 10.1093/icesjms/fsq005

Howell, D., Schueller, A. M., Bentley, J. W., Buchheister, A., Chagaris, D., Cieri, M., et al. (2021). Combining ecosystem and single-species modeling to provide ecosystem-based fisheries management advice within current management systems. Front. Mar. Sci. 7:1163. doi: 10.3389/fmars.2020.607831

Irwin, B. J., Wilberg, M. J., Jones, M. L., and Bence, J. R. (2011). Applying structured decision making to recreational fisheries management. Fisheries 36, 113-122. doi: 10.1080/03632415.2011.10389083

June, F. C., and Carlson, F. T. (1971). Food of young Atlantic menhaden, Brevoortia tyrannus, in relation to metamorphosis. Fish. Bull. 68, 493-512.

Koehn, L. E., Essington, T. E., Levin, P. S., Marshall, K. N., Anderson, L. G., Bundy, A., et al. (2020). Case studies demonstrate capacity for a structured planning process for ecosystem-based fisheries management. Can. J. Fish. Aquat. Sci. 999, 1-19. doi: 10.1002/9780470959480.ch1

Levin, P. S., Essington, T. E., Marshall, K. N., Koehn, L. E., Anderson, L. G., Bundy, A., et al. (2018). Building effective fishery ecosystem plans. Mar. Policy 92, 48-57. doi: 10.1016/j.marpol.2018.01.019

Liljestrand, E. M., Wilberg, M. J., and Schueller, A. M. (2019). Estimation of movement and mortality of Atlantic menhaden during 1966-1969 using a Bayesian multi-state mark-recovery model. Fish. Res. 210, 204-213. doi: 10. 1016/j.fishres.2018.10.015

Link, J. (2010). Ecosystem-Based Fisheries Management: Confronting Tradeoffs. New York, NY: Cambridge University Press.

Link, J., Overholtz, W., O’Reilly, J., Green, J., Dow, D., Palka, D., et al. (2008). The Northeast US continental shelf Energy Modeling and Analysis exercise (EMAX): ecological network model development and basic ecosystem metrics. J. Marine Syst. 74, 453-474. doi: 10.1016/j.jmarsys.2008.03.007

Link, J. S., Ihde, T. F., Harvey, C. J., Gaichas, S. K., Field, J. C., Brodziak, J. K. T., et al. (2012). Dealing with uncertainty in ecosystem models: the paradox of use for living marine resource management. Prog. Oceanogr. 102, 102-114. doi: 10.1016/j.pocean.2012.03.008

Lynch, P. D., Brush, M. J., Condon, E. D., and Latour, R. J. (2010). Net removal of nitrogen through ingestion of phytoplankton by Atlantic menhaden Brevoortia tyrannus in Chesapeake Bay. Mar. Ecol. Prog. Ser. 401, 195-209. doi: 10.3354/ meps08389

Maguire, J. J. (2009). Report on the Evaluation of the Chesapeake Bay Fisheries Science Program: Atlantic Menhaden Research Program_Laurel. Annapolis, MD: National Oceanic and Atmospheric Administration. 32.

McLeod, K. L., and Leslie, H. M. (2009). "Why ecosystem-based management?" in Ecosystem-Based Management for the Oceans, eds K. McLeod and H. Leslie (Washington, DC: Island Press), 3-12.

McNamee, J. E. (2018). A Multispecies Statistical Catch-At-Age Model for A MidAtlantic Species Complex. dissertation, Narragansett, RI: University of Rhode Island Graduate School of Oceanography.
Munroe, T. A., and Smith, J. W. (2000). Menhadens. An overview of the biology, ecology, and fisheries of the clupeoid fishes occurring in the Gulf of Maine. Northeast Fisheries Science Center Reference Document 00-02. Woods Hole, MA: Northeast Fisheries Science Center, 142-160.

National Marine Fisheries Service [NMFS] (2003). Supplement to the Endangered Species Act Section 7 Consultation. Biological Opinion and Incidental Take Statement of October 2001. Maryland, MD: Silver Spring.

National Marine Fisheries Service [NMFS] (2020). Fisheries of the United States, 2018. U.S. Department of Commerce, NOAA Current Fishery Statistics No. 2018. Available online at: https://www.fisheries.noaa.gov/national/commercialfishing/fisheries-united-states-2018 (accessed March 19, 2021).

National Oceanic and Atmospheric Administration Chesapeake Bay Fisheries Ecosystem Advisory Panel [NOAA CBFEAP] (2006). Fisheries Ecosystem Planning for the Chesapeake Bay. Maryland, MD: American Fisheries Society, Bethesda, 410 .

Nesslage, G. M., and Wilberg, M. J. (2019). A performance evaluation of surplus production models with time-varying intrinsic growth in dynamic ecosystems. Can. J. Fish. Aquat. Sci. 76, 2245-2255. doi: 10.1139/cjfas-2018-0292

Nicholson, W. R. (1978). Movements and population structure of Atlantic menhaden indicated by tag returns. Estuaries 1, 141-150. doi: 10.2307/1351455

Northeast Fisheries Science Center [NEFSC] (2006). Report of the 43rd Northeast Regional Stock Assessment Workshop: Stock Assessment Review Committee (SARC) Consensus Summary of Assessments. Northeast Fisheries Science Center Ref. Doc. 06-16. Woods Hole, MA: Northeast Fisheries Science Center, 400.

Overton, A. S., Griffin, J. C., Margraf, F. J., May, E. B., and Hartman, K. J. (2015). Chronicling long-term predator responses to a shifting forage base in Chesapeake Bay: an energetics approach. Trans. Am. Fish. Soc. 144, 956-966. doi: 10.1080/00028487.2015.1045989

Patrick, W. S., and Link, J. S. (2015). Myths that continue to impede progress in ecosystem-based fisheries management. Fisheries 40, 155-160. doi: 10.1080/ 03632415.2015.1024308

Peterman, R. M., and Anderson, J. L. (1999). Decision analysis: a method for taking uncertainties into account in risk-based decision making. Hum. Ecol. Risk Assess.: Int. J. 5, 231-244. doi: 10.1080/10807039991289383

Pichegru, L., Grémillet, D., Crawford, R. J. M., and Ryan, P. G. (2010). Marine no-take zone rapidly benefits endangered penguin. Biol. Lett. 6, 498-501. doi: 10.1098/rsbl.2009.0913

Pikitch, E., Boersma, P. D., Boyd, I. L., Conover, D. O., Cury, P., Essington, T., et al. (2012). Little Fish, Big Impact: Managing a Crucial Link in Ocean Food Webs. Washington, DC: Lenfest Ocean Program, 108.

Plagányi, É. E., Punt, A. E., Hillary, R., Morello, E. B., Thébaud, O., Hutton, T., et al. (2014). Multispecies fisheries management and conservation: tactical applications using models of intermediate complexity. Fish Fisheries 15, 1-22. doi: 10.1111/j.1467-2979.2012.00488.x

Punt, A. E., MacCall, A. D., Essington, T. E., Francis, T. B., Hurtado-Ferro, F., Johnson, K. F., et al. (2016). Exploring the implications of the harvest control rule for Pacific sardine, accounting for predator dynamics: a MICE model. Eco. Model. 337, 79-95. doi: 10.1016/j.ecolmodel.2016.06.004

Rice, J., and Duplisea, D. (2014). Management of fisheries on forage species: the test-bed for ecosystem approaches to fisheries. ICES J. Mar. Sci. 71, 143-152. doi: 10.1093/icesjms/fst151

Rose, K. A., Sable, S., DeAngelis, D. L., Yurek, S., Trexler, J. C., Graf, W., et al. (2015). Proposed best modeling practices for assessing the effects of ecosystem restoration on fish. Ecol. Modell. 300, 12-29. doi: 10.1016/j.ecolmodel.2014.12. 020

Schaaf, W. E. (1975). Status of the gulf and Atlantic menhaden fisheries and implications for resource management. Mar. Fish. Rev. 37, 1-9.

Schaaf, W. E. (1979). An analysis of the dynamic population response of Atlantic menhaden, Brevoortia tryannus, to an intensive fishery. Rapp. R.-V. Reun. Cons. Int. Explor. Mer 177, 243-251.

Schaaf, W. E., and Huntsman, G. R. (1972). Effects of fishing on the Atlantic menhaden stock: 1955-1969. Trans. Am. Fish. Soc. 101, 290-297. doi: 10.1577/ 1548-8659(1972)101<290:eofota>2.0.co;2

Scharf, F. S., Manderson, J. P., Fabrizio, M. C., Pessutti, J. P., Rosendale, J. E., Chant, R. J., et al. (2004). Seasonal and interannual patterns of distribution and diet of bluefish within a Middle Atlantic Bight estuary in relation to abiotic and biotic factors. Estuaries 27, 426-436. doi: 10.1007/bf02803535 
Sissenwine, M. P., and Shepherd, J. G. (1987). An alternative perspective on recruitment overfishing and biological reference points. Can. J. Fish. Aquat. Sci. 44, 913-918. doi: 10.1139/f87-110

Smith, A. D., Brown, C. J., Bulman, C. M., Fulton, E. A., Johnson, P., Kaplan, I. C., et al. (2011). Impacts of fishing low-trophic level species on marine ecosystems. Science 333, 1147-1150. doi: 10.1126/science.1209395

Smith, L. A., Link, J. S., Cadrin, S. X., and Palka, D. L. (2015). Consumption by marine mammals on the Northeast US continental shelf. Ecol. App. 25, 373-389. doi: $10.1890 / 13-1656.1$

Southeast Data Assessment and Review [SEDAR] (2015). SEDAR 40 - Atlantic Menhaden Stock Assessment Report. North Charleston, SC: SEDAR, 643.

Southeast Data Assessment and Review [SEDAR] (2020a). SEDAR 69 - Atlantic Menhaden Benchmark Stock Assessment Report. North Charleston, SC: SEDAR, 691.

Southeast Data Assessment and Review [SEDAR] (2020b). SEDAR 69 Atlantic Menhaden Ecological Reference Points Stock Assessment Report. North Charleston, SC: SEDAR, 560

Thayer, J. A., Hazen, E. L., García-Reyes, M., Szoboszlai, A., and Sydeman, W. J. (2020). Implementing ecosystem considerations in forage fisheries: san Francisco Bay herring case study. Mar. Policy 118:103884. doi: 10.1016/j. marpol.2020.103884

Uphoff, J. H. Jr., and Sharov, A. (2018). Striped bass and atlantic menhaden predator-prey dynamics: model choice makes the difference. Mar. Coast. Fish. 10, 370-385. doi: $10.1002 / \operatorname{mcf} 2.10030$

Uphoff, J. H. (2003). Predator-prey analysis of striped bass and Atlantic menhaden in upper Chesapeake Bay. Fisheries Manag. Ecol. 10, 313-322. doi: 10.1046/j. 1365-2400.2003.00366.x

Vaughan, D. S., Merriner, J. V., and Schaaf, W. E. (1986). Detectability of a reduction in a single year class of a fish population. J. Elisha Mitchell Sci. Soc $102,122-128$.

Viverette, C. B., Garman, G. C., McIninch, S. P., Markham, A. C., Watts, B. D., and Macko, S. A. (2007). Finfish-waterbird trophic interactions in tidal freshwater tributaries of the Chesapeake Bay. Waterbirds 30(Suppl. 1), 50-62. doi: 10.1675/ 1524-4695(2007)030[0050:ftiitf]2.0.co;2
Vogelbein, W. K., Zwerner, D. E., Kator, H., Rhodes, M. W., and Cardinal, J. (1999). Mycobacteriosis of striped bass from Chesapeake Bay. Research on recreational fishes and fisheries, VIMS Spec. Sci. Rept. 139, 53-58.

Walter, J. F. III, Overton, A. S., Ferry, K. H., and Mather, M. E. (2003). Atlantic coast feeding habits of striped bass: a synthesis supporting a coast-wide understanding of trophic biology. Fisheries Manag. Ecol. 10, 349-360. doi: 10.1046/j.1365-2400.2003.00373.x

Walters, C. J., Christensen, V., Martell, S. J., and Kitchell, J. F. (2005). Possible ecosystem impacts of applying MSY policies from single-species assessment. ICES J. Mar. Sci. 62, 558-568. doi: 10.1016/j.icesjms.2004. 12.005

Whitehead, J. C., and Harrison, J. (2017). Socioeconomic Analysis of the Atlantic Menhaden Commercial Bait and Reduction Fishery: A Report to the Atlantic States Marine Fisheries Commission. Arlington, VA: Atlantic States Marine Fisheries Commission. 180.

Williams, E. H., and Shertzer, K. W. (2015). Technical Documentation of the Beaufort Assessment Model (BAM). U.S. Department of Commerce, NOAA Technical Memorandum NMFS-SEFSC-671. Beaufort, NC: National Oceanic and Atmospheric Administration. 43.

Conflict of Interest: The authors declare that the research was conducted in the absence of any commercial or financial relationships that could be construed as a potential conflict of interest.

Copyright (C) 2021 Anstead, Drew, Chagaris, Cieri, Schueller, McNamee, Buchheister, Nesslage, Uphoff, Wilberg, Sharov, Dean, Brust, Celestino, Madsen, Murray, Appelman, Ballenger, Brito, Cosby, Craig, Flora, Gottschall, Latour, Leonard, Mroch, Newhard, Orner, Swanson, Tinsman, Houde, Miller and Townsend. This is an openaccess article distributed under the terms of the Creative Commons Attribution License (CC BY). The use, distribution or reproduction in other forums is permitted, provided the original author(s) and the copyright owner(s) are credited and that the original publication in this journal is cited, in accordance with accepted academic practice. No use, distribution or reproduction is permitted which does not comply with these terms. 